BMC

Veterinary Research

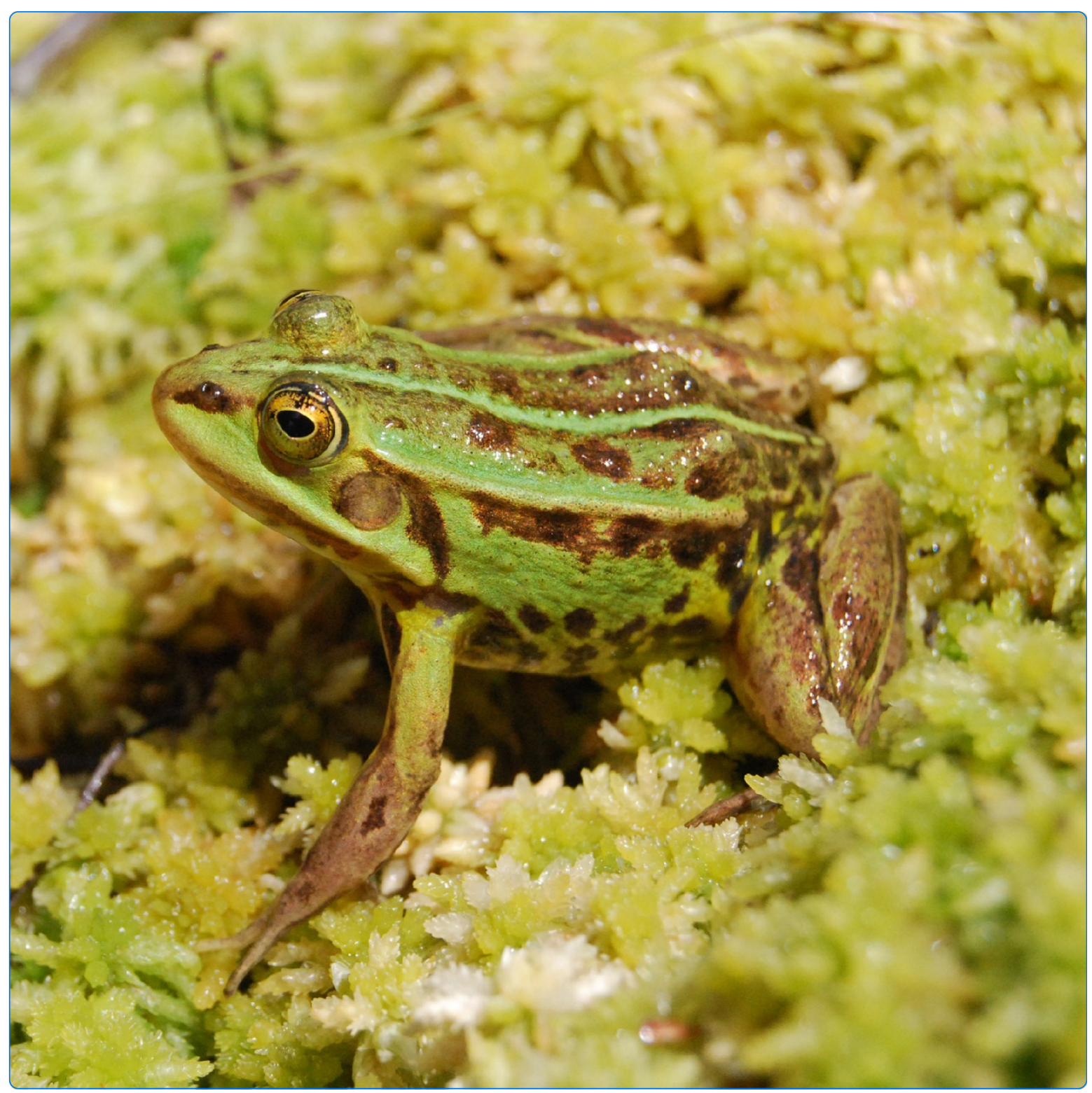

Tolerance of fungal infection in European water frogs exposed to Batrachochytrium dendrobatidis after experimental reduction of innate immune defenses

Woodhams et al.

C Biomed Central 


\title{
Tolerance of fungal infection in European water frogs exposed to Batrachochytrium dendrobatidis after experimental reduction of innate immune defenses
}

\author{
Douglas C Woodhams $s^{1,4^{*}}$, Laurent Bigler ${ }^{2}$ and Rachel Marschang ${ }^{3}$
}

\begin{abstract}
Background: While emerging diseases are affecting many populations of amphibians, some populations are resistant. Determining the relative contributions of factors influencing disease resistance is critical for effective conservation management. Innate immune defenses in amphibian skin are vital host factors against a number of emerging pathogens such as ranaviruses and the amphibian chytrid fungus Batrachochytrium dendrobatidis (Bd). Adult water frogs from Switzerland (Pelophylax esculentus and P. lessonae) collected in the field with their natural microbiota intact were exposed to $B d$ after experimental reduction of microbiota, skin peptides, both, or neither to determine the relative contributions of these defenses.

Results: Naturally-acquired Bd infections were detected in 10/51 P. lessonae and 4/19 P. esculentus, but no disease outbreaks or population declines have been detected at this site. Thus, this population was immunologically primed, and disease resistant. No mortality occurred during the 64 day experiment. Forty percent of initially uninfected frogs became sub-clinically infected upon experimental exposure to $B d$. Reduction of both skin peptide and microbiota immune defenses caused frogs to gain less mass when exposed to $B d$ than frogs in other treatments. Microbiota-reduced frogs increased peptide production upon $B d$ infection. Ranavirus was undetectable in all but two frogs that appeared healthy in the field, but died within a week under laboratory conditions. Virus was detectable in both toe-clips and internal organs.
\end{abstract}

Conclusion: Intact skin microbiota reduced immune activation and can minimize subclinical costs of infection. Tolerance of $B d$ or ranavirus infection may differ with ecological conditions.

Keywords: Amphibian, Antimicrobial peptide, Chytridiomycosis, MALDI-MS, Microbiota, Pelophylax, Ranavirus

\section{Background}

Experimental studies are needed in disease ecology to determine the relative importance of factors influencing disease outcome. Results can be applied to conservation management of amphibians encountering a variety of infectious diseases emerging with global change [1-5]. Two predominant amphibian pathogens associated with global

\footnotetext{
* Correspondence: dwoodhams@gmail.com

'Institute of Evolutionary Biology and Environmental Studies, University of Zurich, Winterthurerstrasse 190, Zurich CH-8057, Switzerland

${ }^{4}$ Department of Ecology and Evolutionary Biology, University of Colorado, N122 Ramaley, 334 UCB, Boulder, CO 80309-0334, USA

Full list of author information is available at the end of the article
}

population declines are ranaviruses and the amphibian chytrid fungus Batrachochytrium dendrobatidis (Bd).

Ranaviruses are large icosahedral DNA viruses belonging to the family Iridoviridae. They have been detected in fish, amphibians and reptiles. Ranavirus associated disease in amphibians has been reported in the Americas, Europe, and Asia, and ranaviruses have also been detected in amphibians in Australia $[4,6]$. To our knowledge, there are no previous reports of ranavirus occurring in wildcaught amphibians in Switzerland.

$B d$ is the causal agent of chytridiomycosis, an amphibian disease capable of producing epizootics and perhaps species extinctions [3,7]. The fungus is top-ranking in

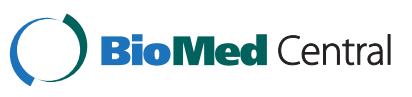


the most recent Amphibian Conservation Action Plan [2]. In Europe, the earliest archived specimens with $B d$ infections were found in 1998 [8], however, recent studies have detected the fungus in Switzerland from much older samples (N. Peyer and B. Schmidt, unpublished data), and both a Swiss strain and a "global panzootic lineage" have been identified in Switzerland ([9]; M.C. Fisher, pers. comm.). Infection of wild amphibians has been documented in ten European countries and appears to be widespread (http://www.Bd-maps.net/). As in other regions, the disease affects some host species more than others $[8,10]$. Therefore, attention to disease resistance mechanisms may lead to protective interventions for threatened amphibian species.

In Switzerland, many amphibian populations have declined in recent years, and $70 \%$ of the 20 species are on the Swiss Red List of threatened species [11]. In contrast, few declines have been reported for populations of water frogs, Pelophylax lessonae and P. esculentus. These species also appear to be relatively tolerant of $B d$ in the wild [8]. Amphibian host mechanisms of disease resistance include a variety of behavioral, innate, and adaptive immune responses [12]. Symbiotic bacteria associated with amphibian skin can inhibit $B d$ and disease development in some species [13-16]. Antimicrobial peptides (AMPs) may also be important against chytridiomycosis $[10,17]$. Nearly 50 skin AMPs were previously described from the water frog complex [18-23], and given the similarity of peptide families, some are probably effective against $B d$ [24]. A unique aspect of this study compared to most previous $B d$-exposure experiments [25], is that adult frogs are examined upon capture from an abundant wild population with their immunity primed, as opposed to examining pathogen-naïve metamorphs. Therefore, adult water frogs are ideal for experiments to test the mechanisms of disease resistance by reducing components of the innate immune system that may confer protection in the wild.

\section{Results}

\section{Ranavirus infection}

Two frogs died within a week of collection. Ranaviruses were deteced by PCR in the liver, kidney, and toe clip of one $P$. esculentus and in the liver of one $P$. lessonae. Virus was isolated on IgH2 from all of the organs tested from both frogs (liver, kidney, heart, lung, and intestine of the first and liver, kidney, heart, and intestine of the second frog). Cell culture supernatant from all isolates was positive for ranavirus by PCR. Sequencing of the PCR products from the livers of each of the frogs showed that a 488 bp portion of the MCP gene was $100 \%$ identical between the two viruses and $97.57 \%$ identical to the corresponding portion of the genome of FV3, the type species of the genus Ranavirus.

\section{Bd infection}

$B d$ was prevalent in field collected water frogs. Swabs were $B d$ positive for 10/51 P. lessonae and 4/19 P. esculentus before experimental treatments (Figure 1a). About $40 \%$ of initially uninfected frogs of both species developed skin infections upon experimental exposure with $B d$ (Figure 1a). Prevalence before or after treatments was not significantly different between species (Fisher's exact tests, $P$ 's $>0.05)$. These infections were sometimes not detected on feet swabs but were detected on body swabs and vice versa (Figure 1b). The proportion of frogs that became infected in each treatment was not significantly different for $P$. lessonae or both species combined (Pearson $X^{2}, P^{\prime}$ s $>0.05$; Figure 2a). The zoospore infection load did not differ significantly among treatments for $P$. lessonae or both species combined (Kruskal-Wallis tests, P's > 0.05). No mortality occurred during the $64 \mathrm{~d}$ experiment. One naturally infected $P$. esculentus died shortly after the experiment (d 80) showing clinical signs of chytridiomycosis and high $B d$ infection loads (Figure 1b).

\section{Mass change}

Nearly all frogs gained mass during the experiment (Figure 2b). Results were similar for both species, thus, the combined results are reported here. Frogs that became infected during the experiment gained slightly, but not significantly, less mass than frogs that remained uninfected (Independent $\mathrm{t}$-test, $\mathrm{t}_{51}=-0.401, P=0.690$ ). However, frogs that were initially infected in the field $(\mathrm{N}=14)$ gained a mean of $1.2 \%$ body mass in comparison with initially uninfected frogs $(\mathrm{N}=53)$ that gained $12.1 \%$ body mass (Independent t-test, $\mathrm{t}_{65}=-2.992 P=0.004$ ). Initially uninfected frogs that were exposed to $B d$ during the experiment $(\mathrm{N}=46)$ gained $11.1 \%$ body mass, and initially uninfected frogs that became infected during the experiment $(\mathrm{N}=20)$ gained $11.3 \%$ body mass. Frogs that were exposed to $B d$ and had both skin peptides and microbiota reduced, gained significantly less weight than frogs in some other treatments, including immune reduced frogs that were not experimentally exposed to $B d$ (Figure 2b; ANOVA, $\mathrm{F}_{4,52}=3.612, P=0.012$ ). Thus, $B d$ infection and immune reduction interacted to produce a growth reduction effect.

\section{Skin peptide recovery}

The dry weight quantity of peptides recovered after norepinephrine administration was significantly correlated to body mass (gbm) for both species (Pearson correlations, $r=0.489$, $n=27, P=0.0048, P$. lessonae; $r=0.753, \mathrm{n}=11, P=0.0038$ $P$. esculentus). Correcting for surface area did not significantly improve this correlation; therefore, we used $\mu \mathrm{g} \mathrm{gbm}^{-1}$ as the unit of peptide quantity recovered. Norepinephrine administration induced significant quantities of skin peptides 


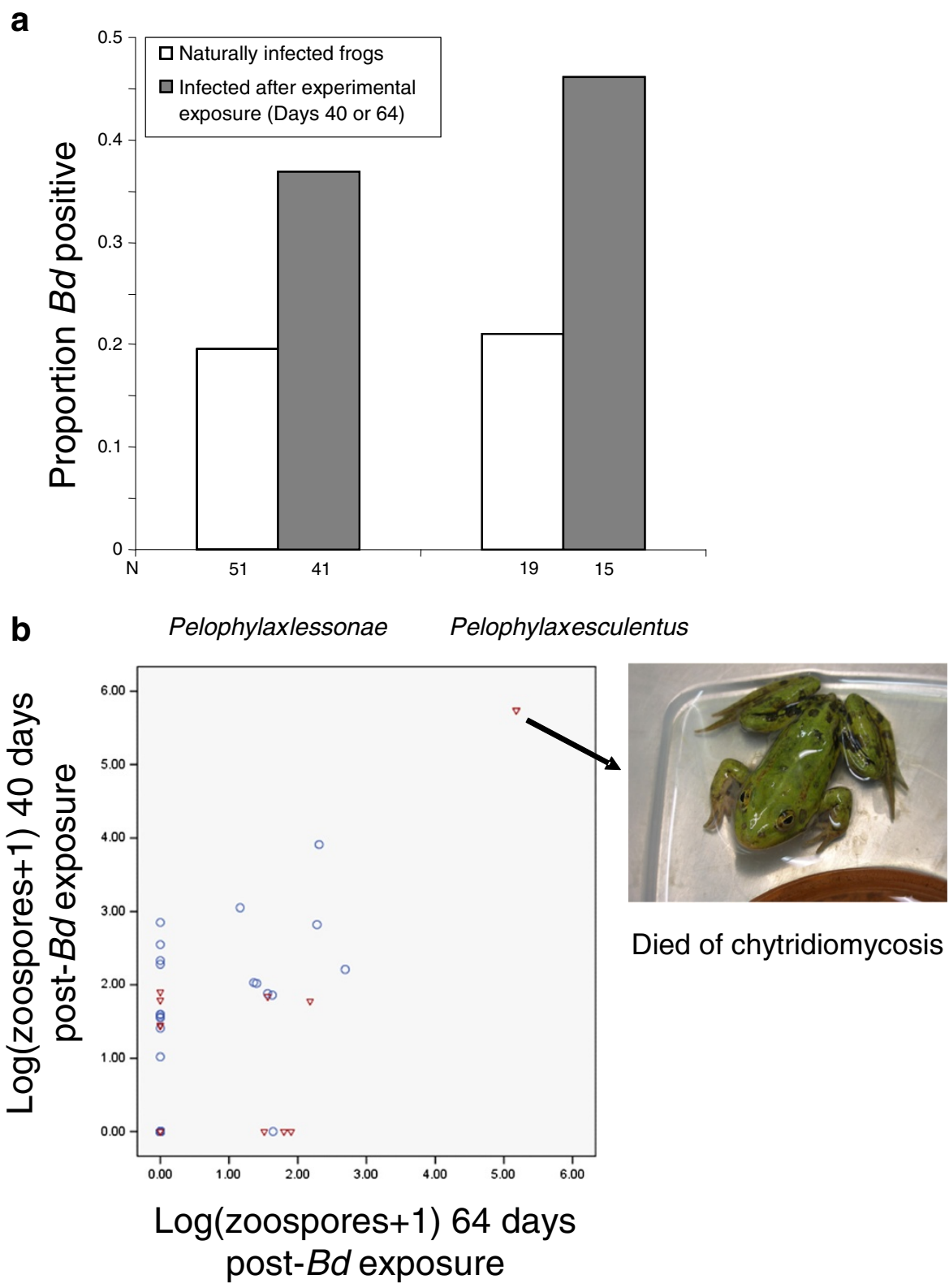

Figure 1 Infection with $\boldsymbol{B}$. dendrobatidis $(\boldsymbol{B} \boldsymbol{d})$. (a) Proportion of water frogs infected with $B d$ determined by quantitative rtPCR. (b) Infection intensities indicating $B d$ zoospore equivalents measured from swabs of Pelophylax esculentus and $P$. lessonae on day 40 post-exposure (feet swabbed) or on day 64 post-exposure (body swabbed after rinse). Frogs that were naturally infected with $B d$ (triangles) or uninfected before beginning the experiment (circles) are indicated. One P. esculentus died on day 80 . This frog was naturally infected, and in addition to the highest $B d$ infection intensity, clinical signs indicative of chytridiomycosis included progressive shedding of skin in water, splayed limbs, inappetence, and lethargy.

from both species in comparison with water-injected controls (Mann-Whitney U-tests, P's $<0.001$; Figure 3). The quantity recovered from controls was (mean \pm SD) $5.0 \pm$ $11.7 \mu \mathrm{g} \mathrm{gbm}^{-1}$ from P. lessonae and $14.7 \pm 13.3 \mu \mathrm{g} \mathrm{gbm}^{-1}$ for $P$. esculentus. $P$. esculentus produced more peptides on average $\left(2741 \mu \mathrm{g} \mathrm{gbm}^{-1}\right)$ than $P$. lessonae $\left(1549 \mu \mathrm{g} \mathrm{gbm}^{-1}\right)$ when stimulated with norepinephrine (Independent t-test, $t_{35}=-4.030, P=0.0003$; Figure 3). Peptide-reduced frogs had recovered peptide quantities similar to nonreduced frogs by 64 days after treatment (Figure 4a). The quantities of peptides recovered on day 64 differed among treatments (Figure 4a). Small sample sizes prohibited testing the treatment effect on $P$. esculentus peptides, but $P$. lessonae with both peptide and microbiota immune defenses reduced and exposed to $B d$ had significantly less peptides than frogs in some 


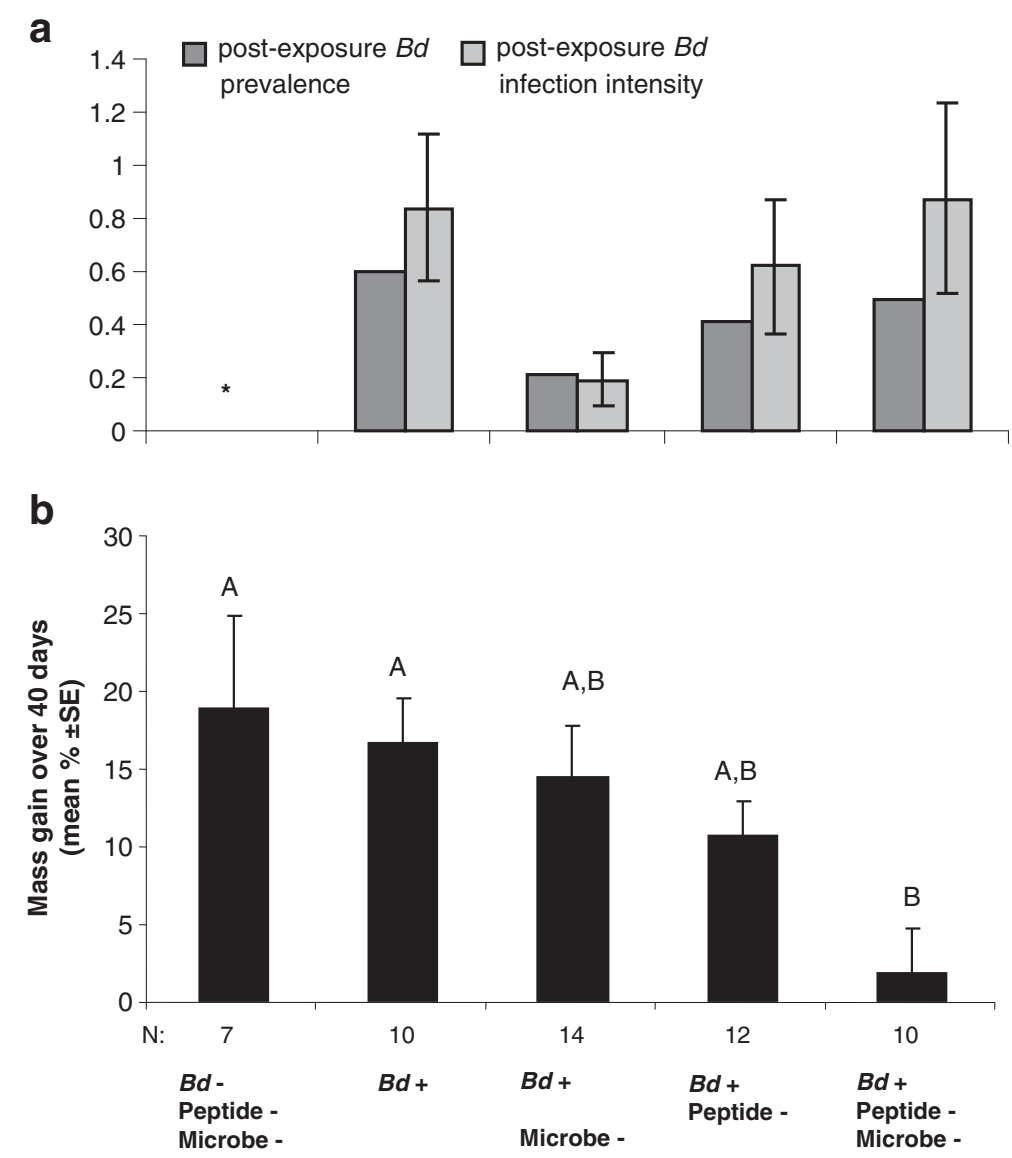

Figure 2 Change in $B$. dendrobatidis $(B d)$ infection status and mass of initially uninfected frogs (Pelophylax esculentus and $P$. lessonae, $\mathbf{N}=53$ ) in each experimental treatment. (a) Proportion of frogs that became infected during the experiment and mean ( \pm SE) infection load expressed as log(zoospore equivalents +1 ). Asterisk indicates infection was detected in one control frog that may have had an undetectable infection before the experiment. (b) Mean percent $( \pm$ SE) mass gain of frogs in each treatment. Letters above bars indicate homogeneous subsets based on a Tukey post-hoc test.

other treatments (ANOVA, $F_{4,47}=6.043, P=0.0006$, Figures 3, 4a).

\section{Relative intensities of peptides}

In addition to the overall quantity of peptides recovered, we measured the relative intensity of peptides within the mass spectra. Mean peptide intensities varied among treatments. In $P$. lessonae, $B d$ exposure and $B d$ exposure with peptide reduction showed the highest intensities, and the control immune-reduced treatment the lowest (ANOVA, $P<0.0001$; Figure 4b). For $P$. esculentus, small sample sizes precluded statistical testing. Dry weight of partially-purified peptides was significantly correlated to the sum relative intensity of peptide peaks identified by MALDI-TOF MS (Pearson correlation, $r=0.376, n=62$, $P=0.003)$.

\section{Peptide production stimulated by infection with Bd} In $P$. lessonae, $B d$ infection significantly increased the quantity of peptides recovered from two treatments:
$B d$ exposed with microbes reduced, and $B d$ exposed with both microbes and peptides reduced (Independent t-tests, $P$ 's $<0.05)$. Thus, an interaction of reduced microbes and $B d$ exposure increased skin peptide production (Figure 5a).

\section{Peptide profiles differed among treatment groups}

The profiles of $P$. lessonae skin peptide ranked intensities were independently analyzed for the effects of $B d$ exposure, $B d$ infection, norepinephrine treatment, and antibiotic treatment with multivariate analyses of variance. Neither $B d$ exposure, $B d$ infection pre-treatment, nor $B d$ infection post-treatment significantly affected peptide profiles (MANOVA, P's $>0.05$ ). Reducing peptides with norepinephrine significantly affected the profiles of recovered peptides (Wilks' Lambda, $F_{22,21}=2.595$, $P=0.016)$. Similarly, reducing microbiota with antibiotics significantly affected peptide profiles (Wilks' Lambda, $\left.F_{22,21}=2.083, P=0.049\right)$. When allocated to one of these four treatment combinations (peptides and/or 


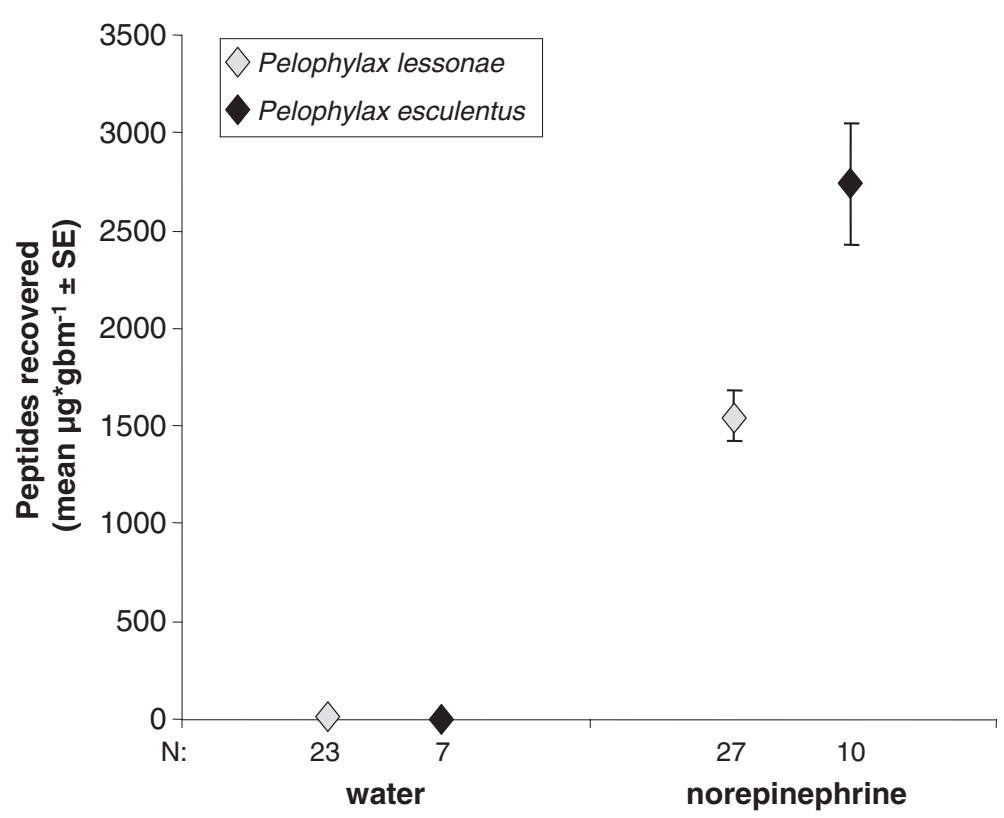

Figure 3 Skin peptide recovery from Pelophylax esculentus and $P$. lessonae upon administration of norepinephrine or water control at the initiation of the experiment.

microbiota reduced or intact) differences in peptide profiles were apparent (Wilks' Lambda, $F_{66,57.6}=1.625, P=0.031$; Figure 5b).

\section{Discussion}

We found that both ranaviral disease and chytridiomycosis can contribute to mortality of water frogs in Switzerland. Field surveys have shown that at many sites, $B d$ infection prevalence is high ([8]; L. R. Davis and U. Tobler unpublished data). However, most frogs that had naturally acquired infections in the field did not show subsequent signs of disease development in the lab. In addition, experimental exposure of frogs to $B d$ zoospores under laboratory conditions ideal for $B d$ growth in culture, did not lead to mortality. Most frogs resisted infection, or tolerated low level infections without developing clinical signs of disease. Thus, we conclude that $P$. esculentus and P. lessonae are largely disease resistant, and infection tolerant, as adults, given the strains of $B d$ occurring in Switzerland. These frogs may experience disease-related mortality at more susceptible life-history stages, but if so, such die-offs have not substantially affected population sizes [11]. In addition, 0 of 528 Pelophylax spp. tadpoles had detectable $B d$ infections when sampled from 16 ponds in Switzerland including ponds with infected adults [26]. Factors leading to the stable co-existence of host populations and the chytrid fungal pathogen are only beginning to be understood [27]. Both the adaptive and innate branches of immunity are involved [12].

By experimentally reducing two components of innate immunity, antimicrobial skin peptides and skin microbiota, we aimed to determine the relative importance of each defense. However, even when both defenses were experimentally reduced, and the frogs were exposed to repeated infectious doses of $B d$, we did not detect increased mortality or even an increase in infection intensity. Thus, the effects of reduced immunity and $B d$ were subclinical.

Subclinical effects of $B d$ have been determined in other systems including Bufo bufo larvae [28], Pseudacris regilla larvae [5], Plethodon cinereus adults [16], and Hyla chrysoscelis and Bufo fowleri metamorphs [29,30]. Here, we found that $B d$ infection and a reduction of both peptide and microbiota immune defenses interacted to produce a growth reduction effect. Our data suggest a trade-off between energy expenditure on growth and immune defense. Given that antimicrobial peptides may be costly to produce, it is not surprising that $P$. lessonae appeared to increase peptide production upon exposure to $B d$ only when microbiota was reduced. Microbiota may extend the host innate immunity against $B d$ [31], thus reducing the need for costly peptide production.

The significant reduction of growth in naturally infected compared to uninfected frogs may indicate cause or consequence of $B d$ infection. When uninfected frogs were experimentally exposed to $B d$ and when they became infected, growth reduction was not simply a result of $B d$ exposure, but an interaction of $B d$ exposure and immune reduction. Thus, factors in addition to natural $B d$ exposure probably contributed to reduced growth in the 14 naturally infected frogs, and these co-factors 


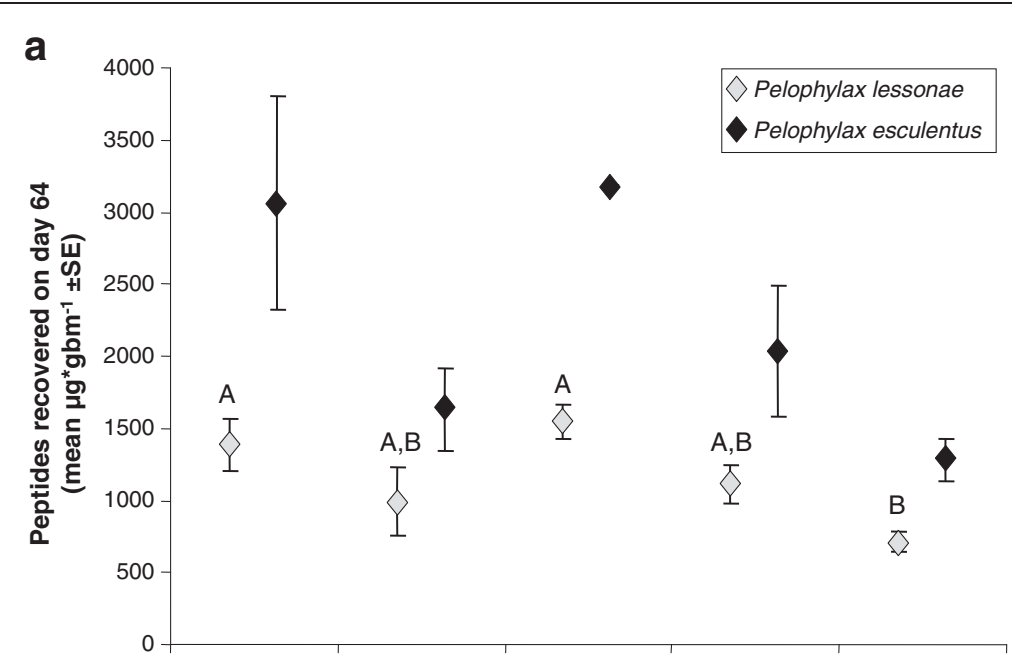

b

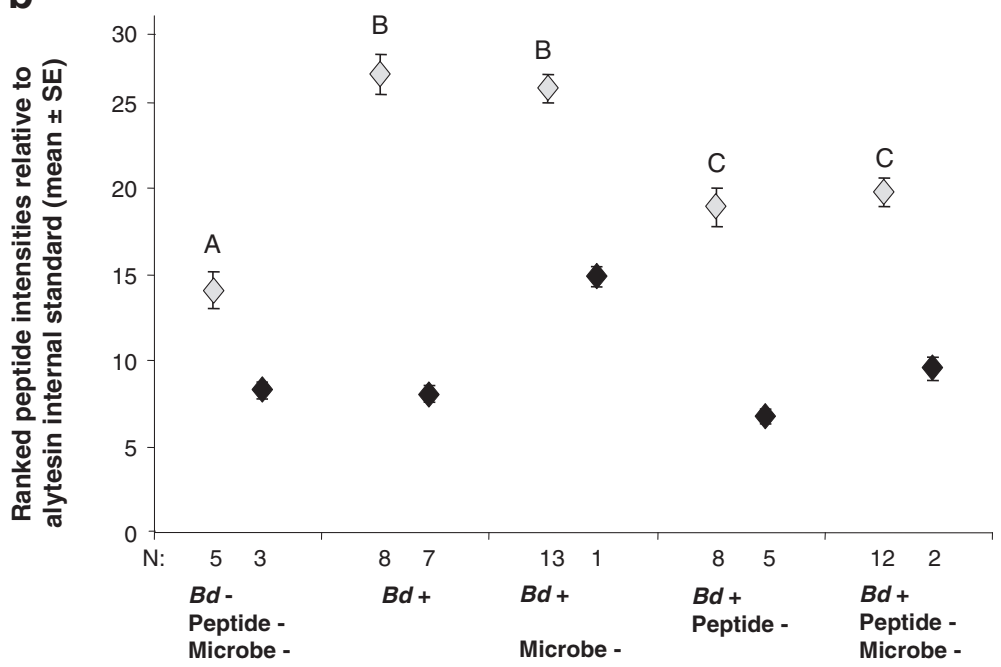

Figure 4 Quantity and relative intensity of skin peptides recovered from Pelophylax esculentus and $P$. lessonae in experimental treatments. (a) Peptide quantities recovered from frogs in each treatment at the end of the experiment indicating that frogs in peptide reduced treatments had recovered peptide stores by 64 days (compare to Figure 3). (b) Comparison of mean skin peptide intensities of samples collected from frogs at the end of each experimental treatment. Letters above bars indicate homogeneous subsets based on a Tukey post-hoc test within $P$. lessonae. Small sample size for $P$. esculentus precluded statistical analysis.

may have contributed to the susceptibility of these frogs in nature.

There are at least three explanations for why water frogs continued to resist chytridiomycosis upon experimental innate-immune reduction: (1) Host frogs increased synthesis or expression of antimicrobial skin peptide defenses upon exposure to $B d$. Skin peptides were initially reduced, but when collected again after $64 \mathrm{~d}$, peptide levels had recovered to previous quantities. (2) Some beneficial bacteria may have persisted on skin despite treatments with broad spectrum antibiotics. Ongoing studies will determine the resistance or resilience of amphibian skin microbiota to antibiotic treatments. (3) Water frogs in this study were collected as adults from a population coexisting with ranavirus and $B d$. Thus, frogs were immunologically primed prior to experimental exposure and may have activated adaptive immune responses. Similarly, wild-caught Hypsiboas crepitans resisted infection in one study and may have been immunologically primed [32]. Amphibians in several other studies were able to clear infections at various temperatures including those conducive to fungal growth [rev. in 33]. Although we did not determine the primary source of disease resistance in this study, it is clear that both $B d$ and the maintenance of innate immunity have subclinical costs to water frogs. Colonization by microbiota may help reduce these costs.

We found that the method of infection diagnosis is important for classifying the effects of $B d$ exposure. 

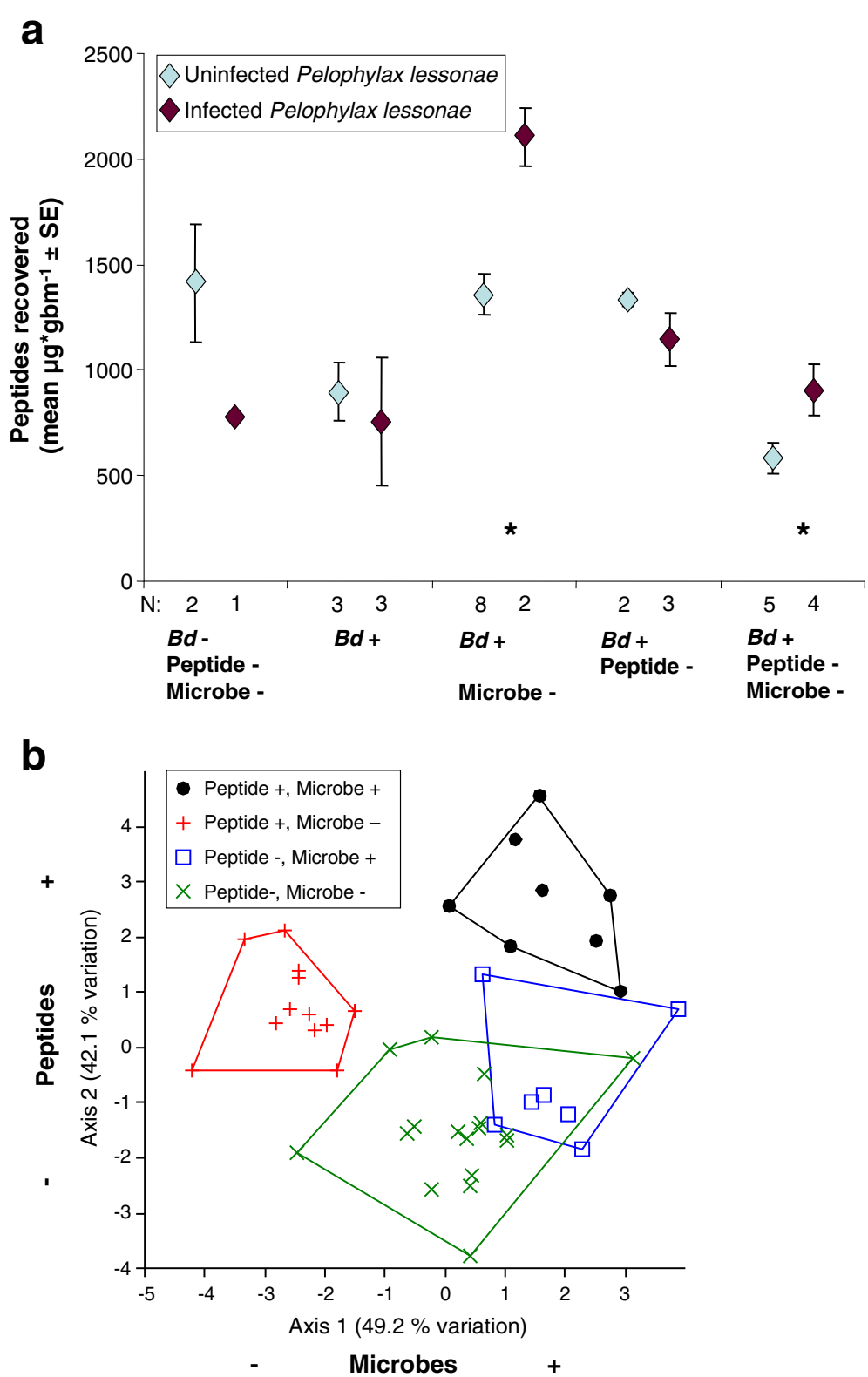

Figure 5 The effect of infection with $B$. dendrobatidis $(B d)$ on the quantity of skin peptides recovered and the effect of treatment on skin peptide profiles from Pelophylax lessonae. (a) Asterisks indicate treatments with statistically significant differences between infected and uninfected frogs. (b) A canonical variates analysis scatter plot showing treatment effects on skin peptide profiles. Axes correspond to frog treatment: Peptides reduced (-) by norepinephrine to intact (+), and microbes reduced $(-)$ by antibiotics to intact (+).

Although numerous studies have shown that hundreds of amphibian species were positive for $B d$ when sampled (http://www.Bd-maps.net/), diagnostic PCR to detect $B d$ DNA does not always detect low-level infections, and thus may underestimate infection prevalence. We found that low level infections can be missed by swabbing at a single time point. We also found differences in detectability depending on body location of swabbing, however this is confounded by differences in swabbing date. Other studies have demonstrated higher infection loads on ventral as opposed to dorsal skin surfaces [34]. In addition, DNA of dead fungal cells can be detected, as well as DNA from zoospores in water or that happen to be on the amphibian skin, but not infecting it [35]. This becomes very important for interpreting the effects of experimental exposure to $B d$ when large doses of zoospores are applied. Researchers use several techniques to discriminate between skin infection and transient pathogen presence: repeating diagnostic qPCR from skin swab samples taken over several days with rinses or water 
changes between sampling periods ([32,35]; this study), microscopy of skin samples or shed skin [36,37], or histology of skin tissue samples [38]. Detecting the effects of the disease chytridiomycosis is usually determined by clinical signs and histological descriptions of disease state [39]. Diseased frogs exhibit increased skin sloughing, inappetance, lethargy, and loss of righting-reflex $[39,40]$. These signs usually occur within hours to days of death [41] and indicate a standard endpoint for euthanasia in experimental trials to reduce animal suffering. Only one frog in our study showed clinical signs of chytridiomycosis; unusual skin sloughing was observed for over 2 months before presentation of lethal disease.

\section{Conclusion}

Amphibian species differ in their tolerance of pathogens such as $B d$ or ranavirus $[4,10]$. Changes in ecological conditions including the microbial communities present in the host environment [42] may influence the immune competence of host amphibians. Intact skin microbiota reduced immune activation and may minimize subclinical costs of infection.

\section{Methods}

\section{Animal collection and husbandry}

We collected seventy water frogs, Pelophylax lessonae (= Rana lessonae) and P. esculentus (= Rana esculenta), from a wetland near the Community of Hinwil, Canton of Zürich, Switzerland $\left(47^{\circ} 18^{\prime} \mathrm{N} / 8^{\circ} 49^{\prime} \mathrm{E}\right.$; $1 \mathrm{~km}$ WSW Hinwil, $22 \mathrm{~km}$ ESE Zürich) in August 2008. The genetics of this population were previously studied $[43,44]$. We captured amphibians by hand and immediately placed them into individual sterile plastic boxes. After swabbing and toeclipping frogs the next day (see below), we placed frogs into new plastic enclosures containing a clay saucer and filter-sterilized tap water. Frogs were fed crickets two to three times weekly after water changes. After acclimation for two weeks, frogs were allocated into one of five treatment regimes and enclosures placed in a randomized block design on shelving in a controlled environment room kept at approximately constant $18^{\circ} \mathrm{C}$ and $14: 10$ light: dark schedule with full spectrum lighting. Collecting permits were provided by the Canton Zürich Office of Landscape and Nature conservation directorate, and all animal procedures were approved by the Veterinary Authority for the canton of Zürich (227/2007) and the Federal Office for the Environment.

\section{Experimental design}

We randomly allocated 67 frogs among five treatment regimes without reference to infection status or species (Table 1). To reduce symbiotic microbiota we added antibiotics (10 units" $\mathrm{ml}^{-1}$ penicillin, $10 \mathrm{ug}^{*} \mathrm{ml}^{-1}$ streptomycin, and $10 \mathrm{ug}^{*} \mathrm{ml}^{-1}$ tetracycline; Sigma, St. Louis, Missouri) to the water and filter sterilized before every water change. These doses were deemed safe and effective in other studies ([45]; L.A. Rollins-Smith pers. comm.). We used filter-sterilized tap water without antibiotics in all other treatments. To reduce antimicrobial skin peptides we administered norepinephrine at a dose that strongly reduces skin peptides in other species $[46,47]$. All other frogs were given amphibian phosphatebuffered saline as a control for injection. After $64 \mathrm{~d}$, peptides were induced from frogs in all treatments. These final peptide samples were analyzed by mass spectrometry (see below). Exposure to $B d$ zoospores occurred on two successive days beginning the day following peptide reduction. We collected zoospores from a Swiss $B d$ isolate (TG 739) by washing 5 day old $1 \%$ tryptone agar plates (grown at $18^{\circ} \mathrm{C}$ ) for $20 \mathrm{~min}$ with sterile frog water. We added approximately $1.5 \times 10^{5}-2 \times 10^{5}$ zoospores, or sterile wash for controls, directly onto each frog sitting in $150 \mathrm{ml}$ water. We determined the viability of zoospores by microscopic examination and counted zoospores stained 1:10 in lugol solution (Sigma) on a heamocytometer. Water was changed one day after the final exposure. Frogs were monitored daily during the $64 \mathrm{~d}$ experiment.

Table 1 Experimental design including sample size for each water frog species, the type of immune reduction, and exposure to $B$. dendrobatidis zoospores

\begin{tabular}{|c|c|c|c|c|c|}
\hline $\begin{array}{l}\text { Treatment } \\
\text { regime }\end{array}$ & $\frac{\mathrm{N}}{P . \text { lessonae }}$ & $\frac{\mathrm{N}}{\text { P. esculentus }}$ & $\begin{array}{l}\text { Antimicrobial } \\
\text { peptide } \\
\text { reduced }\end{array}$ & $\begin{array}{l}\text { Microbe } \\
\text { reduced }\end{array}$ & $\begin{array}{c}B d \\
\text { exposed }\end{array}$ \\
\hline 1 & 5 & 3 & $*$ & * & - \\
\hline 2 & 10 & 5 & & & + \\
\hline 3 & 12 & 2 & & * & + \\
\hline 4 & 8 & 7 & $*$ & & + \\
\hline 5 & 14 & 1 & * & * & + \\
\hline
\end{tabular}

Treatments began before species determination, therefore, sample sizes vary. ${ }^{*}$ indicates immune reduction treatment. 


\section{Ranavirus analysis}

Toe clips from 70 frogs were collected in ethanol and tested for the presence of ranaviral DNA [48]. Two frogs died before the beginning of the experiments and were frozen for later virological testing. Samples from liver, kidney, intestine, lung, and heart were collected in $3 \mathrm{ml}$ Dulbecco's modified Eagle's medium (DMEM) (Biochrom AG, Berlin, Germany) supplemented with antibiotics. Cells were disrupted using a Branson-250 Sonifier at an output level of 30 for 3 impulses and cell debris was pelleted by low speed centrifugation $(1500 \times \mathrm{g}, 10$ minutes at $4^{\circ} \mathrm{C}$ ). The supernatant was used for DNA preparation and virus isolation. For virus isolation, $200 \mu \mathrm{l}$ of supernatant were inoculated onto iguana heart cells (IgH2, ATCC, CCL-108) following the protocol described elsewhere [49]. Samples showing cytopathic effects (CPE) were passaged onto new IgH2. Virus isolates were characterized by type of CPE and sensitivity to chloroform and detection of ranavirus DNA. Toe clips were transferred into DMEM and treated as described above. DNA was prepared from sample homogenates or cell culture supernatant using the DNAeasy ${ }^{\circledR}$ kit (Qiagen GmbH, Hilden, Germany). A PCR targeting a conserved portion of the major capsid protein (MCP) gene of ranaviruses was carried out as described previously [50]. PCR products were sequenced directly. The sequences were compared to the data in GenBank (National Center for Biotechnology Information, Bethesda, USA) online (www.ncbi.nih.gov) using BLASTN and BLASTX options.

\section{Bd analysis}

We swabbed all frogs at four time points with sterile rayon swabs (Milian). Feet only were swabbed $6 \mathrm{~d}$ before the first exposure and at $40 \mathrm{~d}$ post exposure. After rinsing with sterile water, we swabbed the body $11 \mathrm{~d}$ pre-exposure and $64 \mathrm{~d}$ post-exposure. We compared results from both types of swabs. A $B d$ positive result at either pre-exposure timepoint was considered infected before the experiment. If a frog had a $B d$ positive result at either post-exposure timepoint we considered it infected at the end of the experiment. We extracted DNA from swabs using PrepMan Ultra (Applied Biosystems) and detected $B d$ genomic equivalents with quantitative real-time PCR according to Boyle et al. [51]. Standards of 0.1, 1, 10, and 100 zoospore equivalents were obtained from ecogenics $\mathrm{GmbH}$ (Zürich-Schlieren, Switzerland) and run in duplicate. All samples were diluted 1:10 to prevent PrepMan inhibition of the PCR and run in duplicate. When the result was ambivalent, the analysis was repeated. A result below the lowest standard ( 0.1 zoospore equivalents) was considered negative.

\section{Species determination}

Water frogs form a hybridogenic species complex including the parent species Pelophylax ridibundus (R) and $P$. lessonae (L). Hybrid P. esculentus (E) can occur with parent species or in all hybrid populations [52]. Since sexual hybrid populations can potentially exist independently of parent species, we here refer to hybrid $P$. esculentus as a "species". In Switzerland, most water frog populations consist of only $P$. lessonae and $P$. esculentus (LE populations; [44]). These two species can be difficult to distinguish morphologically and microsatellite markers have been identified to distinguish them in northern Europe. We used 16 primer pairs to amplify loci in either the L genome, the $\mathrm{R}$ genome, or both, in a multiplex PCR according to Christiansen and Reyer [52] from toe-tip extracted DNA.

\section{Skin peptide collection and analysis by MALDI-MS}

We induced granular gland secretions by administration of norepinephrine $(40 \mathrm{nmol} / \mathrm{g}$ body mass bitartrate salt, Sigma) by subcutaneous injection $[46,47]$. After administration of norepinephrine, skin secretions were collected for $15 \mathrm{~min}$ in water and acidified with $1 \%$ hydrochloric acid to $\mathrm{pH}<4.0$ to help prevent proteolytic degradation of the samples. Skin secretions were then partially purified by passing over C-18 Sep-Pak cartridges (Waters Corp., Milford, Massachusetts) activated with acetonitrile, eluted in buffer containing 70\% acetonitrile and $0.1 \%$ trifluoroacetic acid (TFA), spun dry at $60^{\circ} \mathrm{C}$, weighed, and stored at $-20^{\circ} \mathrm{C}$. The total dry weight quantity of partially-purified skin secretions containing peptides recovered per gram body mass $\left(\mu \mathrm{g} \mathrm{gbm}^{-1}\right)$ was determined for each sample.

We analyzed peptide samples collected at day 64 from all frogs by matrix-assisted laser desorption/ionization (MALDI) mass spectrometry (MS) using an Autoflex I time-of-flight mass spectrometer (Bruker Daltonics $\mathrm{GmbH}$, Bremen, Germany) equipped with a $337 \mathrm{~nm}$ nitrogen laser. Samples were reconstituted in water and standardized at a concentration of $1 \mathrm{mg} \mathrm{ml}^{-1}$. A $5 \mu \mathrm{l}$ sample solution was diluted with a solution of $10 \mu \mathrm{l}$ water $+0.1 \%$ trifluoroacetic acid containing $10 \mu \mathrm{g} \mathrm{ml}^{-1}$ alytesin (amino acid sequence: pE-GRLGTQWAVGHLM$\mathrm{NH}_{2}$ ) internal peptide standard (GeneScript). We spotted $1 \mu \mathrm{l}$ on a "Prespotted AnchorChip" target prepared with $\alpha$-cyano-4-hydroxycinnamic acid as matrix (HCCA, Bruker), waited $1 \mathrm{~min}$, and rinsed with $7 \mu \mathrm{l} 10 \mathrm{mM}$ aqueous ammonium dihydrogen phosphate buffer containing $0.1 \%$ TFA. Instrument calibration was obtained using signals from the HCCA matrix at m/z 379.09 and a mixture of standard peptides composed of Bradykinin 1-7 (m/z 757.40), angiotensin II ( $\mathrm{m} / \mathrm{z} 1046.54)$, angiotensin I (m/z 1296.69), renin substrate $(\mathrm{m} / \mathrm{z} 1758.93)$, ACTH clip 18-39 (m/z 2465.20) and Somatostatin 28 $(\mathrm{m} / \mathrm{z} 3147.47)$ all obtained from the peptide calibration standard II mix (Bruker).

For each mass spectrum we calculated the intensity of each peptide peak in proportion to the alytesin external 
standard. Since peptides may vary in ionization and detectability by MALDI-TOF MS, intensities do not indicate absolute quantities of each peptide. We rank transformed peptide intensity data to satisfy Box's test for homogeneity of covariance matrices. The mean ranked peptide intensity was calculated for each treatment. We independently explored the effects of various factors on peptide profiles with multivariate analyses of variance including antibiotic treatment, norepinephrine treatment, exposure to $B d$, and infection with $B d$. Effects of significant factors were then visualized with a canonical variates analysis (PAST v.2.10 http://folk.uio.no/ ohammer/past).

\section{Statistical analyses}

All statistics were carried out using SPSS Statistics 17.0 (SPSS Inc., Chicago, IL, USA). We used standard parametric analyses when the data met the assumptions of normal distribution of data and homogeneity of variances (Levene's statistic). Otherwise, we used homologous non-parametric tests as indicated.

\section{Competing interests}

The authors declare that they have no competing interests.

\section{Authors' contributions}

DCW designed and carried out the experiment. LB analyzed skin peptide samples with MALDI mass spectrometry. RM analyzed samples for ranavirus. All authors participated in drafting the manuscript and have read and approved the final manuscript.

\section{Acknowledgments}

The authors thank D. Christiansen and J. Hall for field assistance and S. Roethlisberger for assistance with microsatellite analysis. T. Papp and C. Schäfer assisted with ranavirus analyses. J. Hall extracted and quantified peptides. U. Tobler, C. Gieger, L. Davis, and A.-M. Metz assisted with qPCR. D. C.W. was supported by grants from the Swiss National Science Foundation (31-125099) and the Claraz Stiftung. The authors also thank the Institute of Evolutionary Biology and Environmental Studies, University of Zurich for financial support for ranavirus analyses carried out at the University of Hohenheim.

\section{Author details}

${ }^{1}$ Institute of Evolutionary Biology and Environmental Studies, University of Zurich, Winterthurerstrasse 190, Zurich CH-8057, Switzerland. ${ }^{2}$ Institute of Organic Chemistry, University of Zurich, Winterthurerstrasse 190, Zurich $\mathrm{CH}-8057$, Switzerland. ${ }^{3}$ Institute for Environmental and Animal Hygiene, University of Hohenheim, Garbenstrasse 30, Stuttgart 70599, Germany. ${ }^{4}$ Department of Ecology and Evolutionary Biology, University of Colorado, N122 Ramaley, 334 UCB, Boulder, CO 80309-0334, USA.

Received: 4 May 2011 Accepted: 11 October 2012

Published: 23 October 2012

\section{References}

1. Daszak P, Berger L, Cunningham AA, Hyatt AD, Green DE, Speare R: Emerging infectious diseases and amphibian population declines. Emerg Infect Dis 1999, 5:1-23.

2. Gascon C, Collins JP, Moore RD, Church DR, McKay JE, Mendelson JR Jr: Amphibian Conservation Action Plan. Gland and Cambridge: IUCN/SSC Amphibian Specialist Group; 2007.

3. Skerratt LF, Berger L, Speare R, Cashins S, McDonald KR, Phillott AD, Hines HB, Kenyon N: Spread of chytridiomycosis has caused the rapid global decline and extinction of frogs. Ecohealth 2007, 4:125-134.
4. Gray MJ, Miller DL, Hoverman JT: Ecology and pathology of amphibian ranaviruses. Dis Aquat Org 2009, 87:243-266.

5. Romansic JM, Johnson PTJ, Searle CL, Johnson JE, Tunstall TS, Han BA, Rohr JR, Blaustein AR: Individual and combined effects of multiple pathogens on Pacific treefrogs. Oecologia 2011, 166:1029-1041.

6. Chinchar VG, Hyatt A, Miyazaki T, Williams T: Family Iridoviridae: Poor viral relations no longer. Curr Top Microbiol Immunol 2009, 328:123-170.

7. Lips KR, Brem F, Brenes R, Reeve JD, Alford RA, Voyles J, Carey C, Livo L, Pessier AP, Collins JP: Emerging infectious disease and the loss of biodiversity in a neotropical amphibian community. Proc Nat Acad Sci U S A 2006, 103:3165-3170.

8. Garner TWJ, Walker S, Bosch J, Hyatt AD, Cunningham AA Chytridiomycosis in Europe. Emerg Infect Dis 2005, 11:1639-1641.

9. Farrer RA, Weinert LA, Bielby J, Garner TW, Balloux F, Clare F, Bosch J, Cunningham AA, Weldon C, du Preez LH, Anderson L, Kosakovsky Pond SL, Shahar-Golan R, Henk DA, Fisher MC: Multiple emergences of genetically diverse amphibian-infecting chytrids include a globalized hypervirulent recombinant lineage. Proc Nat Acad Sci U S A 2011, 108:18732-18736.

10. Woodhams DC, Ardipradja K, Alford RA, Marantelli G, Reinert LK, Rollins-Smith LA: Resistance to chytridiomycosis varies among amphibian species and is correlated with skin peptide defences. Anim Cons 2007, 10:409-508.

11. Schmidt BR, Zumbach S: Rote Liste der gefährdeten Amphibien der Schweiz. Hrsg. Bundesamt für Umwelt, Wald und Landschaft, Bern, und Koordinationsstelle für Amphibien- und Reptilienschutz in der Schweiz, Bern. BUWAL-Reihe: Vollzug Umwelt. 2005:48S. http://www.karch.ch/karch/d/pro/ rolia/media/RoteListe_BUWAL_KARCH.pdf.

12. Rollins-Smith LA, Woodhams DC: Amphibian Immunity: Staying in Tune with the Environment. In Ecoimmunology. Edited by Demas GE, Nelson RJ. New York: Oxford University Press; 2012:92-143.

13. Harris RN, James TY, Lauer A, Simon MA, Patel A: Amphibian pathogen Batrachochytrium dendrobatidis is inhibited by the cutaneous bacteria of amphibian species. Ecohealth 2006, 3:53-56.

14. Harris RN, Brucker RM, Walke JB, Becker MH, Schwantes CR, Flaherty DC, Lam BA, Woodhams DC, Briggs CJ, Vredenburg VT, Minbiole KP: Skin microbes on frogs prevent morbidity and mortality caused by a lethal skin fungus. ISME J 2009, 3:818-824.

15. Harris RN, Lauer A, Simon MA, Banning JL, Alford RA: Addition of antifungal skin bacteria to salamanders ameliorates the effects of chytridiomycosis. Dis Aquat Org 2009, 83:11-16.

16. Becker MH, Brucker RM, Schwantes CR, Harris RN, Minbiole KPC: The bacterially produced metabolite violacein is associated with survival of amphibians infected with a lethal fungus. Appl Environ Microbiol 2009, 75:6635-6638.

17. Woodhams DC, Rollins-Smith $L A$, Carey C, Reinert LK, Tyler MJ, Alford RA: Population trends associated with antimicrobial peptide defences against chytridiomycosis in Australian frogs. Oecologia 2006, 146:531-540.

18. Simmaco M, Mignogna G, Barra D, Bossa F: Novel antimicrobial peptides from skin secretion of the European frog Rana esculenta. FEBS Lett 1993, 324:159-161.

19. Simmaco M, Mignogna G, Barra D, Bossa F: Antimicrobial peptides from skin secretions of Rana esculenta: Molecular cloning of cDNAs encoding esculentin and brevinins and isolation of new active peptides. J Biol Chem 1994, 269:11956-11961.

20. Ali MF, Knoop FC, Vaudry H, Conlon JM: Characterization of novel antimicrobial peptides from the skins of frogs of the Rana esculenta complex. Peptides 2003, 24:955-961.

21. Artemenko KA, Samgina TY, Lebedev AT, Doyle JR, Llewellyn LE, Bilusich D, Bowie JH: Host-defence peptides from the skin secretion of the European marsh frog Rana ridibunda. Mass Spec 2007, 4:79-88.

22. Ghavami S, Asoodeh A, Klonisch T, Halayko AJ, Kadkhoda K, Kroczak TJ, Gibson SB, Booy EP, Naderi-Manesh H, Los M: Brevinin-2R(1) semiselectively kills cancer cells by a distinct mechanism, which involves the lysosomal-mitochondrial death pathway. J Cell Mol Med 2008, 12:1005-1022.

23. Samgina TY, Artemenko KA, Gorshkov VA, Ogourtsov SV, Zubarev RA, Lebedev AT: De novo sequencing of peptides secreted by the skin glands of the caucasian green frog Rana ridibunda. Rapid Comm Mass Spec 2008, 22:3517-3525.

24. Rollins-Smith LA, Conlon JM: Antimicrobial peptide defences against chytridiomycosis, an emerging infectious disease of amphibian populations. Dev Comp Immunol 2005, 29:589-598. 
25. Kilpatrick MA, Briggs CJ, Daszak P: The ecology and impact of chytridiomycosis: an emerging disease of amphibians. Trends Ecol Evol 2010, 25:109-118.

26. Lüthi MD: Ecological and genetic structure of water frog populations: the role of habitat characteristics and invasive species, Master Thesis, Institute of Evolutionary Biology and Environmental Studies. Switzerland: University of Zurich; 2011.

27. Briggs CJ, Knapp RA, Vredenburg VT: Enzootic and epizootic of the chytrid fungal pathogen of amphibians. Proc Nat Acad Sci U S A 2010, 107:9695-9700.

28. Garner TWJ, Walker S, Bosch J, Leech S, Rowcliffe JM, Cunningham AA, Fisher MC: Life history tradeoffs influence mortality associated with amphibian pathogen Batrachochytrium dendrobatidis. Oikos 2009, 118:783-791.

29. Parris MJ, Baudoin DR: Interactive effects of a heavy metal and chytridiomycosis on gray treefrog larvae (Hyla chrysoscelis). Copeia 2004 2:344-350.

30. Parris MJ, Cornelius TO: Fungal pathogen causes competitive and developmental stress in larval amphibian communities. Ecology 2004, 85:3385-3395

31. Woodhams DC, Rollins-Smith LA, Briggs CJ, Vredenburg VT, Simon MA Billheimer D, Shakhtour B, Shyr Y, Briggs CJ, Rollins-Smith LA, Harris RN: Symbiotic bacteria contribute to innate immune defenses of the threatened mountain yellow-legged frog, Rana muscosa. Biol Cons 2007, 138:390-398.

32. Márquez M, Nava-González F, Sánchez D, Calcagno M, Lampo M: Immmunological Clearance of Batrachochytrium dendrobatidis Infection at a Pathogen-optimal Temperature in the Hylid Frog Hypsiboas crepitans. Ecohealth 2010, 7:380-388.

33. Woodhams DC, Bosch J, Briggs CJ, Cashins S, Davis LR, Lauer A, Muths E, Puschendorf R, Schmidt BR, Sheafor B, Voyles J: Mitigating amphibian disease: strategies to maintain wild populations and control chytridiomycosis. Frontiers in Zoology 2011, 8:8.

34. North S, Alford RA: Infection intensity and sampling locality affect Batrachochytrium dendrobatidis distribution among body regions on gree-eyed tree frogs Litoria genimaculta. Dis Aquat Org 2008, 81:177-188.

35. Hyatt AD, Boyle DG, Olsen V, Boyle DB, Berger L, Obendorf D, Dalton A,

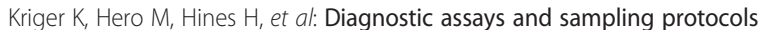
for the detection of Batrachochytrium dendrobatidis. Dis Aquat Org 2007, 73:175-192.

36. Pessier AP: Cytologic diagnosis of disease in amphibians. Vet Clin North Am Exot Anim Pract 2007, 10:187-206.

37. Murphy PJ, St-Hilaire S, Bruer S, Corn PS, Peterson CR: Distribution and pathogenicity of Batraochytrium dendrobatidis in boreal toads from the Grand Teton area of western Wyoming. Ecohealth 2009, 6:109-120.

38. Berger $L$, Speare R, Kent A: Diagnosis of chytridiomycosis in amphibians by histologic examination. Zoo's Print J 2000, 15:184-190.

39. Berger L, Speare R, Daszak P, Green DE, Cunningham AA, Goggin CL, Slocombe R, Ragan MA, Hyatt AD, McDonald KR, et al: Chytridiomycosis causes amphibian mortality associated with population declines in the rain forests of Australia and Central America. Proc Nat Acad Sci U S A 1998, 95:9031-9036.

40. Carey C, Bruzgul JE, Livo L, Walling ML, Kuehl KA, Dixon BF, Pessier AP, Alford RA, Rogers KB: Experimental exposures of boreal toads (Bufo boreas) to a pathogenic chytrid fungus (Batrachochytrium dendrobatidis). Ecohealth 2006, 3:5-21.

41. Berger L, Speare R, Skerratt LF: Distribution of Batrachochytrium dendrobatidis and pathology in the skin of green tree frogs Litoria caerulea with severe chytridiomycosis. Dis Aquat Org 2005, 68:65-70

42. Belden LK, Harris RN: Infectious diseases in wildlife: the community ecology context. Front Ecol Environ 2007, 5:533-539.

43. Semlitsch RD, Schmiedehausen S, Hotz H, Beerli P: Genetic compatibility between sexual and clonal genomes in local populations of the hybridogenetic Rana esculenta complex. Evol Ecol 1996, 10:531-543.

44. Hotz H, Guex GD, Beerli P, Semlitsch RD, Pruvost NBM: Hemiclone diversity in the hybridogenetic frog Rana esculenta outside the area of clone formation: the view from protein electrophoresis. J Zool Syst Evol Res 2008, 46:56-62.

45. Wright KM, Whitaker BR: Pharmacotherapeutics. In Amphibian Medicine and Captive Husbandry. Edited by Wright KM, Whitaker BR. Malabar, Florida: Kreiger Publishing Company; 2001:309-330.
46. Rollins-Smith LA, Reinert LK, O'Leary CJ, Houston LE, Woodhams DC: Antimicrobial peptide defenses in amphibian skin. Integ Comp Biol 2005, 45:137-142.

47. Gammill WM, Fites JS, Rollins-Smith LA: Norepinephrine depletion of antimicrobial peptides from skin glands of Xenopus laevis. Dev Comp Immunol 2012, 37:19-27. doi:10.1016/j.dci.2011.12.012.

48. St-Armour V, Lesbarreres D: Genetic evidence of Ranavirus in toe clips: an alternative to lethal sampling methods. Cons Genet 2007, 8:1247-1250.

49. Papp T, Fledelius B, Schmidt V, Kaján GL, Marschang RE: PCR-sequence characterisation of new adenoviruses found in reptiles and the first successful isolation of a lizard adenovirus. Vet Microbiol 2009, 134:233-240.

50. Marschang RE, Becher P, Posthaus H, Wild P, Thiel HJ, Müller-Doblies U, Kalet EF, Bacciarini LN: Isolation and characterization of an iridovirus from Hermann's tortoises (Testudo hermanni). Arch Virol 1999, 144:1909-1922.

51. Boyle DG, Boyle DB, Olsen V, Morgan JAT, Hyatt AD: Rapid quantitative detection of chytridiomycosis (Batrachochytrium dendrobatidis) in amphibian samples using real-time Taqman PCR assay. Dis Aquat Org 2004, 60:141-148.

52. Christiansen DG, Reyer HU: From clonal to sexual hybrids: genetic recombination via triploids in all-hybrid populations of water frogs. Evolution 2009, 63:1754-1768.

doi:10.1186/1746-6148-8-197

Cite this article as: Woodhams et al:: Tolerance of fungal infection in European water frogs exposed to Batrachochytrium dendrobatidis after experimental reduction of innate immune defenses. BMC Veterinary Research 2012 8:197.

\section{Submit your next manuscript to BioMed Central and take full advantage of:}

- Convenient online submission

- Thorough peer review

- No space constraints or color figure charges

- Immediate publication on acceptance

- Inclusion in PubMed, CAS, Scopus and Google Scholar

- Research which is freely available for redistribution 